\title{
Komplexní vývojové trauma a užívání návykových látek
}

\section{Complex Developmental Trauma and Substance Use Disorder}

\author{
Pavla Doležalová* \\ Centrum epidemiologického a klinického výzkumu závislostí při \\ Národním ústavu duševního zdraví
}

\begin{abstract}
Abstrakt
Trauma a závislost má nepříznivý dopad na zdraví, sociální prostředí jedince, vzdělávání. Cílem textu je stručný úvod do problematiky jevů vývojového traumatu a užínání návykových látek u adolescentních dívek v institucionální výchově a dále představit výsledky výzkumné studie zabývající se rozsahem raných traumatických událostí u adolescentních dívek v institucionální výchově a prevalencí vybraných návykových látek u adolescentních dívek v institucionální výchově v porovnání s běžnou školní populací. V praktické části studie byla využita kvantitativně orientovaná analýza vývojového traumatu a užívání návykových látek u dívek v institucionální výchově; výzkumná studie byla realizována jako součást projektu s názvem: Prevence psychosociálních rizik nezletilých žen a matek s rizikovým chováním prostřednictvím korekce vztahové vazby (2016). Byl použit dotazník: Záznam časných traumatických událostí (Bremner, Bolus, \& Mayer, 2007). Pro analytické komparace byla použita vybraná data z Evropské školní studie o alkoholu a jiných drogách (ESPAD, 2015). Získané statistické údaje poukazují na vysoký rozsah vývojového traumatu u sledovaných dívek a na vysokou míru prevalence uživání drog během jednoho roku (na rozdíl od běžné školní populace).
\end{abstract}

Kličová slova: komplexní vývojové trauma, závislosti, adolescentní dívky, vulnerabilita.

\begin{abstract}
Trauma and addiction have a negative impact on health, the social environment of the individual, education. Research confirms the negative impact of developmental trauma in adult and confirms other negative effects on quality of life aspects (Wegman et al. 2009; Suliman et al. 2009; Najavits et al., 2007). The aim of the text is a brief introduction to the problems of complex developmental trauma and substance use among adolescent girls in residential institutions under special education setting. We present the results of a research study dealing with early traumatic events and the prevalence of selected drugs among adolescent girls in residential institution. The study provides quantitative analysis of developmental trauma and substance use among girls in institutional residentions. The
\end{abstract}

\footnotetext{
*Korespondenční autorka: Pavla Doležalová, Centrum epidemiologického a klinického výzkumu závislostí, Národní ústav duševního zdraví, Topolová 748, 25067 Klecany, Česká republika.

E-mail:polezalova1@gmail.com
} 
research study was conducted as part of a project entitled: Prevention of Psychosocial Risks of Underage Women and Mothers with Risk Behavior through Relationship Correction (2016). The study used questionnaire: Recording of Early Traumatic Events (Bremner et al. 2007) and selected data from the European School Study on Alcohol and Other Drugs (ESPAD, 2015). The research sample consisted of 122 respondents, aged 15-19, placed in residential institutions. Data were collected in 2016. No such data from prevalence studies have been collected so far among these girls. Our findings suggest a significant prevalence of many traumatic phenomena in early childhood among respondents. It is a developmental trauma, mainly due to disorganized attachment and adverse family relationships. Our findings show a high level of general and emotional trauma. Over the past year, more than $61 \%$ used cannabis, $44 \%$ used amphetamines and $18 \%$ had a volatile substance. The level of cannabis use is more than double among respondents, seven times in the case of inhalants and 18 times in the case of amphetamines. The statistical differences presented by the chi-square test results are highly significant in all cases (p-value $<0.001$ ). Statistically, these comparative findings regarding the prevalence of substance use in the last month or year are highly significant. Compared to the reference group, there are indeed significant differences. Discussion. The results show a high extent of developmental trauma in the girls under review and a high prevalence of drug use within one year (as opposed to the general school population). However, we cannot deduce from the data obtained the causal nature of the relationship between trauma and drug use. Experiences of early traumatic events appear to increase mental vulnerability. Increased levels of substance use in the girls studied are seen as a means of self-healing emotional pain caused by developmental trauma. The obtained statistical data indicate a high extent of complex developmental trauma in girls in residential institutions. There is also a high prevalence of drug use within one year among respondents. These girls placed in residential institutions are a highly vulnerable group in terms of their complex needs and mental health and quality of life. Interventions should focus on a holistic approach and link the treatment of trauma, addiction and mental health.

Keywords: Complex developmental trauma, substance use disorder, adolescent girls, vulnerability.

\section{Úvod}

V tomto textu se zabýváme dvěma fenomény komplexním vývojovým traumatem a prevalencí užívání návykových látek. Fenomén komplexního vývojového traumatu vystihuje Van der Kolk (2005) termínem „komplexní vývojové trauma“ („Complex Developmental Trauma“). Jedná se o trauma způsobené chronickými a dlouhodobými vývojově nepříznivými událostmi (např́klad: sexuální nebo fyzické zneužití, domácí násilí), objevujícími se v raném životě často v rodinném systému obsahujícím fyzické, emoční, výchovné zanedbávání a špatné zacházení.

Fenomén užívání návykových látek mezi adolescentními dívkami umístěnými do programů institucionální výchovné péče je z perspektivy školství a individuálních zdravotních rizik podceněnou realitou, která vytváří tenze mezi legislativními normami a specifickými potřebami jedince a možnostmi zaměření prevence, léčby nebo i „harm reduction“.

Problematika prevalence uživání návykových látek dívkami a rozsah vývojového traumatu u dívek v institucionální výchově je dlouhodobě podceňovaným a systémově neřešeným zdravotním rizikem, jež vyžaduje všeobecně akceptovaný př́stup bio-psycho-socio-spirituální 
model a z něj vyplývající opatření z oblastí adiktologické, speciálně pedagogické a zdravotní. Vzhledem k nedostatku dat týkajících se rozsahu vývojového traumatu hodlá tato studie přispět ke zkoumání těchto jevů a k metodickým podnětům.

Záměrem následujícího článku je poskytnout čtenáři stručný úvod do problematiky jevu vývojového traumatu a užívání návykových látek u adolescentních dívek v institucionální výchově a dále představit výsledky výzkumné studie zabývající se rozsahem raných traumatických událostí u adolescentních dívek v institucionální výchově a prevalencí vybraných návykových látek u adolescentních dívek v institucionální výchově v porovnání s běžnou školní populací.

\section{Teoretická východiska problematiky}

\section{Trauma a raná citová vazba}

Charakteristické pro celkové trauma je velmi stresující zážitek nebo zásadní životní traumatická událost, které vedou k mnoha změnám psychologickým, emocionálním a biologickým, ke změně postojů i hodnot nebo víry. Expozice traumatu vede k silnému zážitku, který závažně narušuje integritu psychických i fyzických funkcí.

SAMHSA (2015) definuje trauma jako, individuální odezvu na traumatickou událost nebo několik traumatických událostí nebo řadu nečekaných zážitků poškozujících fyzické či emocionální oblasti nebo ohrožující dlouhodobě nepříznivě individuální funkce a ovlivňující fyzickou, sociální, emocionální a spirituální pohodu, události, prožitky a smysl.“

Podle APA (2017) trauma představuje emocionální reakce na děsivou událost, jako je např́íklad nehoda, znásilnění, př́rodní pohroma. Bezprostředně po traumatické události je typický šok a popření. Dlouhodobější reakce po traumatu se vyznačují nepředvídatelnými reakcemi, retrospektivními vzpomínkami (flashback), napjatými vztahy, somatickými symptomy (bolení hlavy, nevolnost, únava). Tyto symptomy jsou normální reakcí na „nenormální“ zážitek z prožití traumatu. Lidé, kteří prožili traumatickou událost, mají řadu různých symptomů i těžkostí, které se manifestují variabilními způsoby, aniž by byly přičítány prožitému traumatu.

Komplexní vývojové trauma zasahuje vývoj dítěte v mnoha aspektech života a může mít nepříznivý dopad na zdraví, sociální prostředí jedince, vzdělávání a celkově může přispívat k vulnerabilitě užívání návykových látek.

Vývojové trauma se nejčastěji objevuje na pozadí interpersonálních vztahů v dětství mezi prvotními pečovateli, zejména v primární rodině, náhradními rodiči nebo pěstouny. Primární vztahové postavy ovlivňují duševní zdraví a jeho kapacitu pro seberegulaci emocí, vnímání sama sebe, hloubku důvěry, strachu. Allen (2001) uvádí, že prožitek traumatu v dětství má vliv na a) deficity v citové vazbě a sociálních funkcích; b) neurologický vývoj mozku; c) kognitivní funkce; e) chování; f) sebepojetí a sebevědomí; g) hodnoty a postoje.

Trauma spojené s citovou vazbou v dětství je prř́činou mnoha biologických, sociálních a psychologických symptomů nebo problémů v souvislosti s frustrací, depresí, agresivitou, pocity viny, užívání drog, sebevražedným chováním, problémy s koncentrací, poruchy př́ijmu potravy, rakovinou, komplikacemi v sociálních vztazích (Raby et al., 2017; Martin et al. 2017; Schechter et al., 2017; Monteleone et al., 2017; APA 2013; Nissen, 2016; Bifulco et al., 2006). Rovněž deficity citové vazby předznamenávají nedostatečnou gratifikaci vývojových potřeb, které nemusely být dostatečně rozpoznány primární vztahovou postavou - matkou, pokud sama měla 
traumatické zážitky v raných citových vztazích. Děti, které byly vychovávány v institucionálním prostředí v raném dětství, nemusejí mít naplněnou dostatečně část jejich vývojových potřeb.

Tyto děti mohou být ve vyšším riziku nižší adaptace i schopnosti v překonávání psychické zátěže nebo konfliktních sociálních situací. Jejich strategie zvládání mohou fungovat na bázi vulnerability, nebo naopak mohou být resilientní a nacházet zdroje ve zvládání stresujících a náročných situací (Rutter, 2007). Přičemž psychickou vulnerabilitou lze rozumět sklon k senzitivnosti či zranitelnosti, $\mathrm{k}$ tendencím rozvoje duševních potíží, poruch v chování či emocí; obecně je možno tedy vulnerabilitu považovat za opak resilience (Paulík, 2017). K vulnerabilitě a její míře přispívají environmentální faktory, kvalita raných citových vazeb a zážitky raných traumat.

Některé osobnosti, jak uvádí (Shore, 2001), mají těžkosti s porozuměním významu určitých sociálních situací, jsou náchylnější k takovým psychickým poruchám a chorobám, jakými jsou deprese, rozvoj PTSP, závislostní chování (in Rothschild, 2000). Proto tedy je jisté citové vazbě přikládán fundamentální význam pro zdravý psychosociální vývoji dítěte (Shore, 2001; Siegel, 1999; van der Kolk, 1989).

Traumatické události prožité v dětství bývají základem pro rozvoj disorganizované citové vazby. V průběhu dospívání a dospělosti se problémy spojenés traumatem manifestují do variabilní komorbidity, a to včetně rozvoje závislostí na návykových látkách (Dozier, Mc Clough-Stovall, \& Albus, 2008 in Cassidy, Shaver 2008). Řada studií prokazuje spojení užívání drog a nejistou citovou vazbou a zejména s disorganizovanou citovou vazbou (Golder, Gillmore, Spieker, \& Morrison, 2005; Lachlan, 2010). U lidí se závislostí na alkoholu byla prokázaná vyšší vulnerabilita v souvislosti s traumatem v dětství Doležalova (2016). Emoční zneužívání a sexuální zneužití v dětství v rodinném prostředí hraje roli v etiologii poruch spojených s užíváním drog (Barnard, 2011).

\section{Důsledky vývojového komplexního traumatu}

Symptomy PTSD se mohou u některých jedinců objevit kdykoliv po prožití traumatické události, to znamená po několika měsících i letech, také jako důsledek vývojového komplexního traumatu. Po traumatické události je běžné zažívat stresové reakce. Pokud se symptomy objeví po třech měsících a způsobují značný distres nebo narušují práci, studium a běžný život, je vhodné vyhledat terapii (Dorrepaal, Thomaes, Hoogendoorn, Veltman, Draijer, \& Van Balkom, 2014). Ovšem PTSD se obtížně zjišt'uje jako důsledek vývojového traumatu, nebot' komplexní vývojové trauma se odehrává v raném dětství nebo i před narozením dítěte, nejčastěji v interpersonálních interakcích s významnými vztahovými osobami (van der Kolk, 2005).

Symptomy PTSD se mohou projevovat na úrovni fyzické, emocionální, psychické a v kombinaci. Charakteristické jsou tř́i hlavní symptomy:

a) intrusivní opakujici se vzpomínky na traumatickou událost, noční můry, záblesk paměti (flashback), spouštěče smyslové, drobné detaily pripomínajicí traumatickou událost (triggers)

b) emocionální otupění a vyhýbáni se lidem, určitým mistům, aktivitám, které připominaji trauma

c) zvýšená vzrušivost, poruchy spánku, těžkosti s koncentrací, snadné rozrušení se a rozhněvání, pocitování nervozity 
Pokud byli děti a adolescenti vystaveni traumatické události, jsou ve vysokém riziku rozvoje PTSD a řady negativních faktorů spojených s chováním, duševními problémy, vzděláváním (Gillies, Maiocchi, Bhandari, Taylor, Gray, \& O’brien, 2016). Schalinski et al (2017) zkoumali disociativní symptomy spojené s traumatem v dětství u žen a jejich výsledky potvrzují abnormální změny na mozku v důsledku posttraumatické poruchy. V návaznosti Schechter et al (2017) zkoumal matky s PTSD a jejich vztahové reakce a rodičovskou stimulaci svých dětí - kojenců. Nabízí se předpoklad, že odmítavé a nejasné reakce matek s PTSD na přirozené projevy dítěte (např. nelibost, křik) mohly být spouštěčem nevyléčeného traumatu matky z jejího dětství.

V souvislosti se zkoumáním vlivu traumatu na fyzické a duševní zdraví, výzkumy potvrzují negativní vliv na zdraví v dospělosti u jedinců, kteří byli v dětství zneužívaní a zažili traumatické události. Spektrum negativních konsekvencí se objevuje v pozdějším životě v oblasti zdraví u jedinců s prožitek dětství traumatické události (Wegman \& Stetler, 2009). Ovšem i v adolescenci při kumulaci traumatických událostí se objevuje asociace s PTSD, úzkostí a depresí. Více traumatických událostí zažitých v životě u adolescentů se podílí na vyšší závažnosti PTSD, než je tomu u jedinců, kteří zažili jedinou traumatickou událost. Vícenásobné zážitky traumatu u adolescentů nezvyšují vždy zásadně míru úzkosti v kontextu vztahových komplikací (Suliman, Mkabile, Fincham, Ahmed, Stein, \& Seedat, 2009). Pravděpodobně charakterové kvality a aspekty odolnosti osobnosti mohou být tlumičem úzkostnosti a nemusí traumatické zážitky být fatální pro adekvátní vztahové interakce. Lidé se závislostí a traumaty mají horší výsledek léčby než pacienti bez historií traumatu (Najavits, 2007).

Traumatický stres zvyšuje riziko duševních onemocnění a zjištění naznačují, že traumatický stres rovněž zvyšuje závažnost symptomů duševních onemocnění. V klinických populacích u žen má asi 30-59\% celoživotní duální diagnostiku posttraumatické stresové poruchy a poruchy užívání látky. Pacienti s oběma poruchami mají závažnější klinický profil než pacienti s poruchami samotnými, s nižším fungováním, s chudším blahobytem a horšími výsledky v celé řadě opatření (Najavits, 2007). V posledních letech bylo vyvinuto a vědecky ověřeno několik slibných léčebných programů speciálně pro souběžnou posttraumatickou stresovou poruchu a poruchu užívání látek (Najavits, Weiss, \& Shaw, 1997; Jhanjee, 2014).

Z širší perspektivy duševního zdraví a jeho dopadů na vývoj jedince, stojí za to uvést strukturovaný přehled oblastí neprríznivého vlivu vývoje dítěte vystaveného komplexnímu traumatu (Cook, Blaustein, Spinazzola, \& Van Der Kolk, 2003):

I. Citová vazba

- problémy s hranicemi

- nejistota ohledně předvídatelnosti světa

- nedůvěra

- podezrrívavost

- sociální isolace

- těžkosti s vyladěním na emocionální stav druhých lidí

- těžkosti v pochopení perspektivy

II. Biologické príčiny

- senzomotorický rozvoj

- problémy s koordinací, vyvážeností, tělového tonusu

- somatizace 
- zvýšený zdravotní problémy v průběhu života (bolest pánve, astma, kožní problémy, autoimunitní poruchy)

III. Regulace emocí

- těžkosti v regulaci emocí

- těžkosti s vyjádřením a popsáním pocitů

- problémy s popsáním vnitřních pocitů

- těžkosti s vyjádřením přání a potřeb

IV. Disociace

- rozlišení změn v nevědomých stavech

- amnézie

- depersonalizace a derealizace

- dva nebo více rozlišení nevědomých stavů

- zhoršené vzpomínky pro příčinu určitých událostí

V. Kontrola chování

- slabá modulace impulsů

- sebedestruktivní chování

- agrese vůči druhým

- poruchy spánku

- poruchy prŕíjmu potravy;

- zneužívání drog

- výstřední povolnost

- opoziční chování

- těžkosti s pochopením a dodržováním pravidel

- oživení traumatu v chování nebo hře

- těžkosti v regulaci pozornosti a výkonnostní

- ztráta zvědavosti

- problémy ve zpracování nových informací

- těžkosti v plánování a očekávání

- problémy s pochopením zodpovědnosti

VI. Kognitivní problémy

- vzdělávací těžkosti

- problémy s rozvojem řeči

- problémy s plánováním

- problémy s orientací v čase a prostoru

- smyslové problémy, orientace v prostoru, akustické, vizuální, motorické těžkosti

VII. Sebepojetí

- ztráta kontinuity, předvídavosti, smyslu pro smysl

- slabé smysl samostatnosti

- narušené vnímaní vlastního těla

- nízké sebevědomí

- hanba a vina 


\section{Vulnerabilita k užívání návykových látek}

Vulnerabilita vůči traumatu se liší podle věku, v němž došlo k expozici traumatické události, dále dle průběhu a doby trvání, hloubky a intenzity traumatu. Zranitelné jsou zejména děti, které prožily komplexní vývojové trauma, jedinci s určitým postižením, ženy, které reagují na traumatickou událost senzitivněji než více resilientní dospělí jedinci. Senzitivní jedinci nemají vytvořeny dostatečné adaptivní obrany a jsou méně odolní vůči stresovým situacím, psychické zátěži, problémům s duševním a fyzickým zdravím.

Mnozí odborníci (Shore, 2001; van der Kolk, 1995, 1989; Siegel, 1999) se shodují na tom, že predispozice k psychickým poruchám, včetně posttraumatické stresové poruchy (PTSP) lze hledat v osobní historii nebo ve stresujících událostech z raného vývoje např́iklad: zanedbávání, tělesné a sexuální zneužívání, selhávání raných vazeb, jednotlivé traumatické události, jako je hospitalizace, smrt rodiče, autonehoda, exodus, násilné události.

Lidé, kteří v raném dětství zažili trauma spojené s citovou vazbou, mají později v životě omezené schopnosti regulovat emocionální napětí, pochopit smysl traumatických zážitků (Rothschild, 2000). Levine (2002) na základě důkazů naznačuje, že jsou zvýšeně senzitivní zvláště malé děti. Podobně další autoři dokazují vysokou zranitelnost a senzitivitu vůči traumatické události v raném dětství v prvním roce života, ale také již i v prenatálním období vývoje (Stern, 1998).

Jedním z mechanismů zvládání traumatu a odpojením se od emocionálních bolestí je sebemedikace. Opiáty nebo jiné návykové látky tlumící psychosomatické problémy a bolesti jsou nekontrolovatelně distribuovány mezi vysoce rizikové jedince (Kingston et al., 2009) V souvislosti se současnými globálními trendy rizik v oblasti veřejného zdraví a vysoké prevalence předávkování a úmrtí u adolescentů a dalších rizikových skupin (Martins, Sampson, Cerdá, \& Galea, 2015) se nabízí mimo vysoké dostupnosti a systémových problémů také souvislost s teorií sebemedikace (Khantzian, 1997).

Tendence k uživání návykových látek bývá cestou k sebeléčbě. Flores (2004) uvádí, že rané trauma a nenasycení potřeb jsou nahrazovány sebemedikací prostřednictvím užívání drog. Jednotlivci s nejistými citovými vazbami nebo disorganizovaným typem citové vazby se mohou sami snažit uzdravit své trauma. Tyto problémy spojené s typickými zážitky úzkosti, nejistoty, studu, bezmoci vedou k seberegulaci pomoci externích zdrojů, jakými jsou užívání drog nebo rizikové chování, jak popisuje Wedekind et al. (2013).

\section{Metodika}

Pro tento článek byla vybrána kvantitativně orientovaná analýza vývojového traumatu a užívání návykových látek u dívek v institucionální výchově.

\section{Cíl výzkumu}

Cílem prezentované studie bylo zjištování

a) rozsahu raných traumatických událostí u adolescentnich dívek vinstitucionální výchově

b) prevalence vybraných návykových látek $u$ adolescentních dívek v institucionální výchově v porovnání s běžnou školní populací 
Výzkumný vzorek

Adolescentní dívky v institucionální výchově byly zkoumány z důvodu jejich vysoké vulnerability a nedostatku dat týkajících se traumatických událostí a prevalence užívání drog.

Velikost výzkumného souboru bylo 122 respondentek. Jednalo se o dívky ve věku 15-19 let, které byly v průběhu roku 2016 umístěny ve školských zařízeních ústavní či ochranné výchovy.

Základní demografické údaje sledovaných dívek jsou tyto: Největší skupina dívek byla ve věku 16 let (49 \%) a ve věku 17 let (33\%). Většina sledovaných dívek navštěvovala střední školu (32\%), přičemž je třeba si povšimnout toho, že téměř $44 \%$ dívek uvedlo jiné varianty týkající se vzdělání. Oněmi jinými variantami můžeme rozumět především přerušení či vyloučení, př́ípadně ukončení vzdělání. Česká národnost byla zastoupena nejvíce $(68,0$ \%), romská národnost tvořila téměř (20\%), zbývající část děvčat se hlásila k jiné národnosti.

\section{Výzkumné nástroje}

V rámci této studie byly využity následující dotazníky:

a) Early Trauma Inventory - Záznam časných traumatických událostí (zkratka: ETISR-SF). Krátký sebeposuzovací dotazník měři dětské trauma objevujicí se pred 18 rokem. Zahrnuje následujici traumatické oblasti: fyzické, emocionální, sexuálni zneuživání a celkové trauma, zaměruje se na frekvenci, nástup, emocionálni vliv a dalši aspekty. Jedná se o nástroj s dobrou validitou, vnitřní konzistenci a reliabilitou v různých kulturnich prostředich.

Respondent označuje položky odpovědní ano jako 1 nebo ne jako 0. Na konci dotazníku jsou tři položku dotazující se na výběr jedné události, která měla největši dopad na jeho či její život a dalši dvě položky měř́ následné reakce, napřiklad strach nebo depersonalizaci (Bremner et al., 2007).

b) Pro analytické komparace byly použity vybraná data z Evropské školní studie o alkoholu a jiných drogách (ESPAD, 2015). Jedná se o každé čtyři roky opakujicí se mezinárodni studii koordinovanou Evropskou agenturou pro drogy a drogové závislosti (EMCDDA) lokalizovanou v Lisabonu v Portugalsku.

\section{Výsledky}

Traumatické události - Analýza časných traumatických událostí u sledovaných dívek

Analýza zhodnocuje výskyt časných traumatických událostí u sledovaných dívek v institucionální výchově. Použitým analytickým nástrojem byl dotazník ETISR-SF (Bremner et al., 2007) věnující základním oblastem časných traumat, a to obecnému traumatu (s 10 otázkami), výskytu fyzického zneužívání (5 otázek), emocionálního zneuživání (5 otázek) a sexuálního zneužívání (6 otázek).

$\mathrm{Na}$ každou př́slušnou otázku respondentky odpovídaly formou ano/ne, tedy jestli se u nich v dětství daná událost/trauma vyskytovala, či nikoliv. Každé kladné odpovědi na danou otázku bylo přisouzené bodové skóre s hodnotou „1“. Suma všech kladných odpovědí na prŕíslušnou 
oblast traumatických událostí pak představovala celkové skóre respondentky v daném ohledu. Následující Tabulka 1 podává základní přehled sledovaných oblastí časného traumatu u dívek v institucionální výchovné péči.

Tabulka 1 Rozsah časných traumatických událostí u dívek v institucionální výchově

(Doležalová, 2018)

\begin{tabular}{llllll}
\hline & Min & Max & Průměr & Standardní odchylka & N (počet odpovědí) \\
\hline Skóre obecného traumatu & 0,00 & 10,00 & 4,43 & 2,35 & 95 \\
\hline Skóre fyzických trestů & 0,00 & 5,00 & 3,40 & 1,55 & 93 \\
\hline Skóre emocionálního zneuživání & 0,00 & 5,00 & 2,79 & 1,74 & 94 \\
\hline Skóre sexuálního zneužívání & 0,00 & 6,00 & 2,26 & 2,06 & 89 \\
\hline
\end{tabular}

Naše poznatky naznačují značný výskyt řady traumatických událostí v raném dětství u sledovaných dívek. Jedná se o vývojové trauma, na kterém se podílí především disorganizovaná citová vazba a nepř́iznivé rodinné vztahy. Naše poznatky prokazují vysokou míru především obecného traumatu (Doležalová, 2018).

Návykové látky - Analýza prevalence uživání vybraných návykových látek u sledovaných dívek a komparace výsledků z jiných dostupných dat o chování obecné školní populace adolescentů (s využitím ESPAD, 2015)

Prevalence užívání návykových látek (dále jen NL) mezi sledovanými dívkami v institucionální výchově je následně porovnána s posledními dostupnými údaji o rizikovém chování obecné školní populace dospívajících dívek získanými z české vlny mezinárodního projektu ESPAD 2015 (European School Survey Project on Alcohol and Other Drugs). Pro testování statistické významnosti rozdílů v úrovni užívání NL mezi sledovanými dívkami a „referenční skupinou“ dívek ze studie ESPAD byl použit tzv. Pearsonův chíkvadrát test dobré shody.

Tabulka 2 Analýza rozdílů v úrovni uživání návykových látek (NL) mezi sledovanou skupinou dívek a referenční skupinou ze školní populace (ESPAD, 2015), prevalence užití NL v posledním roce (\%) (Doležalová, 2018)²

\begin{tabular}{lllll}
\hline Druh návykové látky & & Kanabis & Amfetaminy & Těkavé látky \\
\hline \multirow{2}{*}{ Skupiny } & Sledovaná skupina & $60,7 \%$ & $44,3 \%$ & $18,2 \%$ \\
\cline { 2 - 5 } & Referenční skupina & $29,3 \%$ & $2,4 \%$ & $2,6 \%$ \\
\hline Poměr \% u sledované skupiny vs. \% u referenční skupiny & 2,1 & 18,2 & 7,0 \\
\hline $\begin{array}{l}\text { Pearsonův chí-kvadrát test (stupně volnosti), p-hodnota } \\
\text { (oboustranná) }\end{array}$ & $\begin{array}{l}54,108(1), \\
\mathrm{p}<0,001\end{array}$ & $\begin{array}{l}518,363(1), \\
\mathrm{p}<0,001\end{array}$ & $\begin{array}{l}90,335(1), \\
\mathrm{p}<0,001\end{array}$ \\
\hline
\end{tabular}

Tabulka 2 prezentuje výsledky srovnávací analýzy mezi skupinou sledovaných dívek a děvčaty z obecné školní populace, a to v úrovni užívání dalších vybraných NL. V daném případě jsme se zaměřili na užívání kanabisu, amfetaminů a těkavých látek, tedy dalších NL, kterých uživání u mladé a dospívající populace je poměrně rozšířené.

\footnotetext{
${ }^{2}$ Poznámka: Jako referenční skupina byl použit vzorek N=2886 dívek ve věku 15-16 let ze studie ESPAD, realizované na českých školách v roku 2015. Tento výběr NL jsme zvolili z důvodu jejich zdravotních rizik a z důvodu možnosti komparace dat s referenční skupinou ze studie ESPAD (prevalence v posledním roce).
} 
V průběhu posledního roku, více než dvě pětiny dívek ze sledované skupiny (61\%) užilo kanabis, 44 \% užilo NL ze skupiny amfetaminů a 18 \% těkavé látky. Oproti referenční skupině se jedná v daném ohledu o vskutku markantní rozdíly.

Úroveň užívání kanabisu je u sledovaných dívek více než dvojnásobná, u těkavých látek sedminásobná a $\mathrm{v}$ př́ípadě amfetaminů až 18 násobná. Statistické rozdíly prezentované výsledky chí-kvadrát testů jsou ve všech obou případech vysoce signifikantní (p-hodnota<0,001).

Zkušenosti s užíváním návykových látek ve skupině sledovaných dívek oproti referenční skupině jsou vskutku markantní rozdíly. V průběhu posledního roku, více než dvě pětiny dívek ze sledované skupiny užilo kanabis, přes čtyřicet procent užilo NL ze skupiny amfetaminů a téměř dvacet procent užilo těkavé látky. Úroveň uživání kanabisu je u sledovaných dívek více než dvojnásobná, u těkavých látek sedminásobná a v př́padě amfetaminů až 18násobná v porovnání s běžnou školní populací. Statistické jsou tyto komparativní poznatky ohledně prevalence užíání návykových látek v posledním měsíci nebo roku vysoce signifikantní.

\section{Diskuse}

Naše poznatky naznačují značný výskyt řady traumatických událostí v raném dětství u sledovaných dívek. Statistické výsledky prokazují vysokou míru obecného traumatu a emocionálního traumatu $-v$ případě obecného traumatu byly rozdíly tedy statisticky signifikantní. Naše poznatky prokazují vysokou míru především obecného traumatu, které ale nedosahovaly patologické míry závažnosti. V př́ípadě obecného traumatu byly rozdíly statisticky signifikantní, dále podobně jako fyzické tresty, emocionální zneužívání, sexuální zneužívání (Doležalová, 2018).

Fenomén užívání návykových látek mezi adolescentními dívkami umístěnými do programů institucionální výchovné péče je z perspektivy školství a individuálních zdravotních rizik podceněnou realitou. Dívky žijící v institucionální výchovné péči mají na rozdíl od běžné školní populace mnohonásobně vyšší prevalenci uživání nelegálních návykových látek (Doležalová, 2018). V průběhu posledního roku, více než dvě pětiny dívek ze sledované skupiny (61 \%) užilo kanabis, 44 \% užilo NL ze skupiny amfetaminů a 18 \% těkavé látky. Oproti referenční skupině se jedná v daném ohledu o vskutku markantní rozdíly. Úroveň užívání kanabisu je u sledovaných dívek více než dvojnásobná, u těkavých látek sedminásobná a v př́ípadě amfetaminů až 18 násobná.

Získané statistické údaje poukazují na vysoký rozsah vývojového traumatu u sledovaných dívek a na vysokou míru prevalence užívání drog během jednoho roku (na rozdíl od běžné školní populace). Ze získaných dat nemůžeme vyvozovat kauzální povahu vztahů mezi sledovanými jevy, nelze tedy říci, že vývojové trauma prokazatelně zvyšuje míru užívání návykových látek. Zážitky raných traumatických události zřejmě zvyšují psychickou vulnerabilitu. Zvýšená míra uživání návykových látek u sledovaných dívek je chápána jako prostředek sebeléčby emocionální bolesti způsobené vývojovým traumatem. Je třeba však dodat, že i jedinci s vývojovým traumatem mohou být dostatečně resilientní a že je zde třeba brát v úvahu širší kontext kvality života jedince. 


\section{Závěr}

Dívky v institucionální výchově vykazují vysoký rozsah vývojového traumatu a vysokou prevalenci užívání návykových látek, což je činí výrazně psychicky vulnerabilní. Vysoká míra psychické vulnerability může mít negativní důsledky na duševní zdraví a celkovou kvalitu života.

Vývojové trauma a užívání návykových látek je častou diagnózou v klinických skupinách institucionální péče. Závislost na návykových látkách a trauma závažně ovlivňují průběh a výsledek léčby. Jedinci se zážitky komplexního vývojového traumatu a rozvojem závislosti na návykových látkách jsou vysoce vulnerabilní skupinou. Ve vysokém riziku dopadů na zdraví a sociální život se jedná zejména o mladé ženy a dívky, které jsou i více v riziku stigmatizace. Právě pro jejich vulnerabilitu a riziko sociální stigmatizace a exkluze je vhodné tyto skupiny dlouhodobě sledovat a vyhodnocovat efektivitu intervence v praxi (Schäfer \& Najavits, 2007).

V kontextu současných poznatků je vhodné intervence zaměřovat na společné řešení traumatu, závislosti a dalších dopadů na duševní zdraví a sociální život. Jedná se tedy o holistický př́stup zaměřený na trauma, závislosti i problémy s duševním zdravím a integrované intervence implikovat do klinické praxe.

\section{Grantová podpora}

Výzkumná studie byla realizována jako součást projektu čislo LO1611, s názvem: Prevence psychosociálních rizik nezletilých žen a matek s rizikovým chováním prostřednictvím korekce vztahové vazby, za finanční podpory MŠMT a programu NPU I v NUDZ v roce 2016.

\section{Reference}

Allen, J. G. (2001). Traumatic Relationships and Serious Mental Disorders, Chichester. UK: Wiley.

American Psychiatric Association (2013). Diagnostic and statistical Manual of Mental Disorders: DSM-5 (5 $5^{\text {th }}$ ed,) Washington, D. C.: American Psychiatric Association.

American Psychological Association (2017). Trauma. Získáno 20. ř́ijna 2017 z http://www.apa. org/topics/trauma/index.aspx.

Bernard, M. (2011). Drogová závislost a rodina. Praha: Triton.

Bifulco, A., Kwon, J., Jacobs, C., Moran, P. M., Bunn, A., \& Beer, N. (2006). Adult Attachment Style ss Mediator between Child-Hood Neglect/Abuse and Adult Depression Andanxiety. Social Psychiatry and Psychiatric Epidemiology, 41(10). https://doi.org/10.1007/s00127006-0101-z

Bremner, J. D., Bolus, R., \& Mayer, E. A. (2007). Psychometric properties of the Early Trauma Inventory-Self Report. The Journal of nervous and mental disease, 195(3), 211-218. https://doi.org/10.1097/01.nmd.0000243824.84651.6c

Cassidy, J., \& Shaver, P., R. (Eds.) (2008). Handbook of Attachment: Theory, Research, and Clinical Applications, Second Edition. New York: The Guilford Press. 
Cook, A., Blaustein, M., Spinazzola, J., \& Van Der Kolk, B. (Eds.). (2003). Complex Trauma in Children and Adolescents. Los Angeles: National Child Traumatic Stress Network.

Doležalová, P. (2018). Vztah mezi citovou vazbou a aspekty duševního zdraví adolescentních dívek v institucionální výchovné péči (Nepublikovaná disertační práce). Pedagogická fakulta, Univerzita Karlova, Praha.

Doležalová, P. (2016). Perspektiva teorie citové vazby v léčbě závislostí dospělých klientů. Adiktologie, 16(3), 236-244.

Doležalová, P., Orlíková, B., Kážmer, L., Drbohlavová, B., \& Csémy, L. (2017). Trauma v dětství a adolescenci. Klecany: NUDZ.

Dorrepaal, E., Thomaes, K., Hoogendoorn, A. W., Veltman, D. J., Draijer, N., \& Van Balkom, A. J. (2014). Evidence-Based Treatment for Adult Women with Child Abuse-Related Complex PTSD: a Quantitative Review. European Journal of Psychotraumatology, 5(10), 3402. https://doi.org/10.3402/ejpt.v5.23613

Dozier, M., Mc Clough-Stovall, K. Ch., \& Albus, K. E. (2008). Attachment and Psychopathology in Adulthood in J. Cassidy \& P. R. Shaver (Eds.) Handbook of Attachment (s. 718-744). New York: Guilford Press.

Evropská školní studie o alkoholu a jiných drogách (ESPAD). (2015). Národní monitorovací středisko pro drogy a závislosti. Praha: Úřad vlády České republiky.

Flores, P. J. (2004). Addiction as an Attachment Disorder. Maryland, USA: Jason Aronson.

Gillies, D., Maiocchi, L., Bhandari, A., Taylor, F., Gray, C., \& O’brien, L. (2016). Psychological Therapies for Children and Adolescents Exposed to Trauma. Cochrane Database of Systematic Reviews, 10. https://doi.org/10.1002/14651858.CD012371

Golder, S., Gillmore, M.R., Spieker, S., \& Morrison, D. (2005) Substance Use, Related Problem Behaviors and Adult Attachment in a Sample of High Risk Older Adolescent Women. Journal of Child and Family Studies, 14(2), 181-193. https://doi.org/10.1007/s10826-0055046-6

Jhanjee, S. (2014). Evidence Based Psychosocial Interventions in Substance Use. Indian journal of psychological medicine, 36(2), 112-8. https://doi.org/10.4103/0253-7176.130960

Khantzian, E. (1997). The Self-Medication Hypothesis of Substance Use Disorders: a Reconsideration and Recent Applications. Harvard Review of Psychiatry, 4(5), 231-44. https://doi. org/10.3109/10673229709030550

Kingston, S., \& Raghavan, C. (2009). The relationship of sexual abuse, early initiation of substance use, and adolescent trauma to PTSD. Journal of Traumatic Stress, 22, 65-68. https:// doi.org/10.1002/jts.20381

Lachlan, A., Mcwilliams, \& Bailey, S., J. (2010). Associations Between Adult Attachment Ratings and Health Conditions: Evidence From the National Comorbidity Survey Replication. Health Psychology 29(4), 446-453. https://doi.org/10.1037/a0020061

Levine, A. P., \& Frederick, A. (2002). Prebúdzanie tigra. Pro Familia: Humenné.

Martin, J., Bureau, J., Lafontaine, M., Cloutier, P., Hsiao, C., Pallanca, D., \& Meinz, P. (2017). Preoccupied but not dismissing attachment states of mind are associated with nonsuicidal self-injury. Development and Psychopathology, 29(2), 379-388. https://doi.org/10.1017/ S0954579417000050 
Martins, S. S., Sampson, L., Cerdá, M., \& Galea, S. (2015). Worldwide Prevalence and Trends in Unintentional Drug Overdose: A Systematic Review of the Literature. American Journal of Public Health, 105(11), 2373. https://doi.org/10.2105/AJPH.2015.302843

Monteleone, A. M., Castellini, G., Ricca, V., Volpe, U., De Riso, F., Nigro, M.... Maj, M. (2017). Embodiment Mediates the Relationship between Avoidant Attachment and Eating Disorder Psychopathology. European Eating Disorders Review 25(6), 461-468. https://doi. org/10.1002/erv.2536

Najavits, L. M. (2007). Seeking Safety: An Evidence-Based Model for Substance Abuse and Trauma/PTSD. In K. A. Witkiewitz \& G. A. Marlatt (Eds.), Practical resources for the mental health professional. Therapist's guide to evidence-based relapse prevention (s. 141-167). San Diego, USA: Elsevier Academic Press.

Najavits, L. M., Weiss, R. D., Shaw, S. R. (1997). The Link between Substance Abuse and Posttraumatic Stress Disorder in Women. A research review. The American Journal on Addictions, 6(4), 273-283. https://doi.org/10.1111/j.1521-0391.1997.tb00408

Nissen, K. G. (2016). Correlates of Self-Rated Attachment in Patients With Cancer and Their Caregivers: A Systematic Review and Meta-Analysis. Psycho-Oncology, 25, 1017-1027. https://doi.org/10.1002/pon.4057

Paulík, K. (2017). Psychologie lidské odolnosti. Praha: Grada.

Raby, K., Labella, M., Martin, J., Carlson, E., \& Roisman, G. (2017). Childhood Abuse and Neglect and Insecure Attachment States of Mind in Adulthood: Prospective. Longitudinal Evidence from a High-Risk Sample. Development and Psychopathology, 29(2), 347-363. https://doi.org/10.1017/S0954579417000037

Rothshild, B. (2000). The Body Remembers, The psychofysiology of Trauma and Trauma Treatment. New York: W. W. Norton \& Company.

Rutter, M. (2007). Resilience, Competence, and Coping. Child Abuse \& Neglect 31, 205-209. https://doi.org/10.1016/j.chiabu.2007.02.001

SAMHSA (2015). Trauma-Informed Approach and Trauma-Specific Interventions. Získáno 10. ledna $2018 \mathrm{z}$ https://www.samhsa.gov/nctic/trauma-interventions.

Shore, A. N. (2001). Effects of a Secure Attachment Relationship on Right Brain Development, Affect Regulation and Infant Mental Health. Infant Mental Health Journal, 22(1-2), 7-66. https://doi.org/10.1002/1097-0355(200101/04)22:1<7:AID-IMHJ2>3.0. CO;2-N

Schäfer, I. \& Najavits, L. M. (2007). Clinical challenges in the treatment of patients with posttraumatic stress disorder and substance abuse. Current Opinion in Psychiatry, 20(6), 614-8. https://doi.org/10.1097/YCO.0b013e3282f0ffd9

Schalinski, I., Moran, J. K., Elbert, T., Reindl, V., \& Wienbruch, C. (2017). Oscillatory magnetic brain activity is related to dissociative symptoms and childhood adversities - A Study in Women with Multiple Trauma. Journal of Affective Disorders, 218, 428-436. https://doi. org/10.1016/j.jad.2017.05.009

Schechter, D. S., Moser, D. A., Aue, T., Gex-Fabry, M., Poinet, V. C., Cordero, M. I., \& Rusconi Serpa, S. (2017). Maternal PTSD and Corresponding Neural Activity Mediate Effects of Child Exposure to Violence on Child PTSD Symptoms. PLoS ONE, 12(8). https://doi. org/10.1371/journal.pone.0181066 
Siegel, D. J. (1999). The developing mind, How relationships and the brain interact to shape who we are. New York: Guilford Press.

Stern, D. N. (1998). The Motherhood constellation: A Unified view of parent/infant psychotherapy. London: Karnac books.

Suliman, S., Mkabile, S. G., Fincham, D. S., Ahmed, R., Stein, D. J., \& Seedat, S. (2009). Cumulative Effect of Multiple Trauma on Symptoms of Posttraumatic Stress Disorder, Anxiety, and Depression in Adolescents. Comprehensive Psychiatry 50(2), 121-7. https:// doi.org/10.1016/j.comppsych.2008.06.006

Van Der Kolk, B. (2005). Developmental Trauma Disorder. Psychiatric Annals, 35(5), 401-408. https://doi.org/10.3928/00485713-20050501-06

Van Der Kolk, B. (1989). The Compulsion to Repeat the Trauma: Re-enactment, Revictimization, and Masochism. Psychiatric Clinics of North America, 12(2), 389-411.

Van Der Kolk, B., \& Filsler, R. (1995). Dissociation \& the Fragmentary Nature of Traumatic Memories: Overview \& Exploratory Study. Journal of Traumatic Stress, 8(4), 505-525. https://doi.org/10.1007/bf02102887

Wedekind, D., Bandelow, B., Heitmann, S., Havemann-Reinecke, U., Engel, K. R., \& Huether, G. (2013). Attachment Style, Anxiety Coping, and Personality-Styles in Withdrawn Alcohol Addicted Inpatients. Substance Abuse Treatment, Prevention, and Policy, 8:1. https://doi. org/10.1186/1747-597X-8-1

Wegman, H. L., Stetler, C. (2009). A Meta-Analytic Review of the Effects of Childhood Abuse on Medical Outcomes in Adulthood. Psychosomatic Medicine, 71(8), 805-812. https://doi. org/10.1097/PSY.0b013e3181bb2b46 